\section{Extrahepatic Cholangiocarcinoma in an adult Black Howler Monkey (Primates: Atelidae)}

\author{
Colangiocarcinoma extra-hepático em um Bugio-preto adulto \\ (Primates: Atelidae)
}

\author{
Mariele De Santi* (D), Caroline do Couto ${ }^{2}$ (D) , Gabriel Luiz Montanhim³ (D), Paola Castro Moraes ${ }^{4}$ (D), \\ Paulo Henrique Leal Bertolo ${ }^{5}$ (1) , Rosemeri de Oliveira Vasconcelos ${ }^{6}$ (D) , Acácia Rebello Coutinho ${ }^{7}$ (D) \\ \& Karin Werther ${ }^{8}$ (1)
}

'Veterinary medicine, Doctorade. Programa de Pós-graduação em Medicina Veterinária - PPGMV, Departamento de Patologia Veterinária - DPV, Universidade Estadual Paulista - UNESP, Jaboticabal, SP, Brasil

2Veterinary medicine, Resident. Programa de Residência Multiprofissional em Área Profissional da Saúde - Medicina de Animais Selvagens, Universidade Estadual Paulista - UNESP, Jaboticabal, SP, Brasil

'Veterinary medicine, Doctorade. Programa de Pós-graduação em Cirurgia Veterinária, Departamento de Clínica e Cirurgia Veterinária - DCCV, Universidade Estadual Paulista - UNESP, Jaboticabal, SP, Brasil

${ }^{4}$ Veterinary medicine, Dr. Departamento de Clínica e Cirurgia Veterinária - DCCV, Universidade Estadual Paulista - UNESP, Jaboticabal, SP, Brasil

5Veterinary medicine, Doctorade. Programa de Pós-graduação em Medicina Veterinária - PPGMV, Departamento de Patologia Veterinária - DPV, Universidade Estadual Paulista - UNESP, Jaboticabal, SP, Brasil

6Veterinary medicine, Dr. Laboratório de Imunopatologia, Departamento de Patologia Veterinária - DPV, Universidade Estadual Paulista - UNESP, Jaboticabal, SP, Brasil

`Veterinary medicine, Resident. Programa de Aprimoramento Profissional em Medicina Veterinária - Diagnóstico por Imagem, Universidade Estadual Paulista - UNESP, Jaboticabal, SP, Brasil

${ }^{8}$ Veterinary medicine, Dr. Laboratório de Patologia de Animais Selvagens, Departamento de Patologia Veterinária - DPV, Universidade Estadual Paulista - UNESP, Jaboticabal, SP, Brasil

\begin{abstract}
Over the past years, the number of cases of neoplasms reported in nonhuman primates has increased considerably, with hepatocellular tumors observed in several species. Here, a case of extrahepatic cholangiocarcinoma in an adult male Black Howler Monkey (Alouatta caraya) is presented. The animal, kept as a pet, was admitted to the Veterinary Hospital with clinical signs of cholestasis. After unsuccessful medical treatment, the animal was submitted to a cholecystoduodenostomy. During the surgical procedure, the hepatobiliary system was meticulously observed. The liver showed no macroscopic alterations; however, there was a solid mass throughout the common bile duct. Biopsy specimens were collected from the bile duct mass, liver, and gallbladder for histological and immunohistochemical evaluation. Histological examination of the liver showed diffuse accentuated vacuolization and necrosis, besides hemosiderin accumulation inside hepatocytes. In the portal region, there was an accentuated proliferation of biliary ducts, which were replete with bilirubin. Discrete, neutrophilic, inflammatory infiltrates and fibrosis were also observed. The bile duct mass showed a cellular proliferation of epithelial origin, confirmed on immunohistochemical analysis. The arrangement, characteristics, and growth pattern of these cells revealed a malignant neoplasm. Despite the success of the procedure, the animal died hours later. Cholangiocarcinoma generally presents with a high mortality rate, since its late clinical presentation makes therapy ineffective due to its large extension at the time of diagnosis. The owner did not allow a necropsy; therefore, the presence of other neoplasms and important organ alterations, which may be aggravated the patient's clinical condition, were not confirmed.
\end{abstract}

Keywords: Alouatta caraya, neoplasm, cholecystoenterostomy, histopathology, immunohistochemistry.

\section{Resumo}

Nos últimos anos, o número de casos de neoplasias reportadas em primatas não-humanos têm aumentado consideravelmente, sendo as neoplasias hepatocelulares descritas em diversas espécies. Aqui é relatado um caso de colangiocarcinoma extrahepático em bugio-negro (Alouatta caraya). O animal, mantido como animal de estimação, foi atendido no Hospital Veterinário apresentando sinais de colestase. Após insucesso no tratamento conservativo, foi submetido a colecistoduodenostomia. Durante o procedimento cirúrgico, o sistema hepatobiliar foi cuidadosamente observado. O fígado não demonstrou alterações macroscópicas, entretanto, havia uma massa em toda a extensão do ducto biliar. Biópsia foi realizada para colheita de amostras da massa em ducto biliar, fígado e vesícula biliar para avaliação histopatológica e
How to cite: Santi, M., Couto, C., Montanhim, G. L., Moraes, P. C., Bertolo, P. H. L., Vasconcelos, R. O., Coutinho, A. R., \& Werther, K. (2019). Extrahepatic Cholangiocarcinoma in an adult Black Howler Monkey (Primates: Atelidae). Brazilian Journal of Veterinary Medicine, 41, e101519. doi: 10.29374/2527-2179.bjvm101519

\section{Financial support: None}

Conflict of interests: No conflict of interests declared concerning the publication of this article.

Received: December 12, 2018.

Accepted: June 03, 2019.

The study was carried out at "Serviço de Medicina de Animais Selvagens", Hospital Veterinário "Governador Laudo Natel" and Laboratório de Imunohistoquímica, Departamento de Patologia Veterinária, Universidade Estadual Paulista "Júlio de Mesquita Filho" - UNESP, Jaboticabal, SP, Brasil.

\section{*Correspondence}

Mariele De Santi

Departamento de Patologia Veterinária, Universidade Estadual Paulista - UNESP Via de Acesso Prof.Paulo Donato Castellane s/n, Campus Jaboticabal, CEP14884-900 - Jaboticabal (SP), Brasil E-mail: mariele.santi@gmail.com

Copyright Santi et al. This is an Open Access article distributed under the terms of the Creative Commons Attribution Non-Commercial License which permits unrestricted non-commercial use, distribution, and reproduction in any medium provided the original work is properly cited. 
imunohistoquímica. A avaliação histopatológica do fígado demonstrou difusa e acentuada vacuolização e necrose, além de acúmulo de hemossiderina em hepatócitos. Na região portal, havia acentuada proliferação de ductos biliares, os quais apresentavam-se repletos com bilirrubina. Discreto infiltrado inflamatório neutrofílico e fibrose também foram observados. A massa presente no ducto biliar mostrou proliferação celular de origem epitelial, posteriormente confirmado pela imunohistoquímica. O arranjo, características e padrão de crescimento destas células revelaram uma neoplasia maligna. Embora tenha havido sucesso no procedimento cirúrgico, o animal morreu horas após. Colangiocarcinomas geralmente apresentam alta taxa de mortalidade, uma vez que sua apresentação clínica tardia faz com que o tratamento seja inefetivo devido a grande extensão no momento do diagnóstico. O proprietário não autorizou a necrópsia, portanto a presença de outras neoplasias e alterações em órgãos, que podem ter agravado o quadro clínico do paciente, não foram confirmados.

Palavras-chave: Alouatta caraya, neoplasia, colecistoenterostomia, histopatologia, imunohistoquímica.

\section{Introduction}

Over the past years, the number of cases of neoplasm cases reported in nonhuman primates has increased considerably. The reasons for this increase may be the greater life span and longevity of these individuals, due to improvement in husbandry conditions in zoological parks and research centers, along with the adoption of more detailed pathology protocols (Rylands et al., 2001).

Endocrine neoplasms were the most frequent neoplasms observed in two retrospective surveys in Old World primates (Kaspareit et al., 2007) and New World primates (Catão-Dias et al., 1996). Adrenocortical adenoma was the most frequent endocrine neoplasm observed in several surveys (Lowenstine, 1986; Kaspareit et al., 2007). Colon carcinoma, probably correlated with the presence of acute colitis and chronic mucosal changes, was described in Platyrrhini (Johnson et al., 1996).

Spontaneous hepatocellular tumors have also been described in nonhuman primates. Such reports include cholangiocarcinoma in a Capuchin (Cebus albifrons) (Brown et al., 1980) and a Ring-Tailed Lemur (Lemur catta) (Chang et al., 1979), hepatocellular carcinomas in a Squirrel Monkey (Saimiri boliviensis) (Borda et al., 1996) and a Chimpanzee (Pan troglodytes) (Abe et al., 1993), besides hepatocholangiolar carcinoma in an African Green Monkey (Cercopithecus aethiops) (Seibold \& Wolf, 1973). In Howler Monkeys, there are descriptions of cortical adenomas of the adrenal glands, alveolar carcinoma, renal adenoma (Maruffo, 1967), seminomas (Maruffo, 1967; Maruffo \& Malinow, 1996), and pheochromocytoma (Juan-Sallés, et al., 2009); however, there are no descriptions of hepatocellular tumors in these species.

In general, there are few reports on primary extrahepatic cholangiocarcinomas in the medical literature; despite this, it is known that wide surgical resection offers better prognosis to the patients. However, the late clinical manifestations associated with severe signs of biliary obstruction, often means that these tumors are unresectable at the time of diagnosis (Ka et al., 2018).

In cases of neoplasms, cyst, or trauma where there is no possibility of bile duct repair, bile drainage directly to the intestine through a cholecystoenterostomy is indicated (Mayhew et al., 2002). This procedure restores the bile flow, resolving the cholestasis and tending to improve the patients' clinical condition (Mayhew \& Weisse, 2013).

Herein we present a case report of primary extrahepatic cholangiocarcinoma in an adult male Black Howler Monkey (Alouatta caraya Humboldt, 1812).

\section{Case report}

A 20-years-old Black Howler Monkey (Alouatta caraya), male, kept as a pet (not legalized), was admitted to the Veterinary Hospital "Governador Laudo Natel", in the São Paulo State University (Unesp), School of Agricultural and Veterinarian Sciences, Jaboticabal, Brazil, with a 14-day history of pasty dark feces, malodourous yellowish urine, hyporrexia, and hypodipsia. Physical examination revealed dehydration, icteric ulcerated oral mucosa, and a firm structure palpable in liver topology.

\section{Clinical and laboratory evaluation}

Hematological examination, and radiographic and ultrasonographic investigations were performed. Blood counts revealed an increase in the number of red blood cells (RBC), hemoglobin content (Hb), packed cell volume (PCV), platelets and white blood cells (WBC), represented by 
lymphocytes and monocytes, and a decrease in mean corpuscular volume (MCV), considering Canales-Espinosa et al. (2015) as the reference values for adult male Alouatta pigra (Table 1). Biochemistry revealed an icteric serum and significant increase in the levels of gamma-glutamyl transferase (GGT), aspartate aminotransferase (AST), alanine aminotransferase (ALT) alkaline phosphatase (FA), globulin, direct bilirubin (DBil), indirect bilirubin (IBil) and total-value bilirubin (TBil), considering Canales-Espinosa et al. (2015) as the reference values for adult male Alouatta pigra (Table 1).

Thoracic radiography revealed a structure measuring $4 \times 3 \mathrm{~cm}$, in the accessory lobe of the lung, compatible with neoplastic mass. An accentuated diffuse bronchial opacification was also observed. On ultrasonography, hepatomegaly, diffuse increase in the echogenicity of the hepatic parenchyma, and coarse and granular echotexture were identified. There was a reactive mesentery observed around the hepatic silhouette. The gallbladder was distended with small hyperechoic points in suspension and surrounded by free liquid. Poorly defined echogenic material, consistent

Table 1. Hematological and biochemistry values of an adult Black Howler Monkey (Alouatta caraya), before and after medical treatment.

\begin{tabular}{|c|c|c|}
\hline Parameter & First day* & Eighth day** \\
\hline $\mathrm{RBC}(106 / \mu \mathrm{l})$ & 5.31 & 4.95 \\
\hline $\mathrm{Hb}(\mathrm{g} / \mathrm{dL})$ & 17.2 & 16.4 \\
\hline PCV (\%) & 46.9 & 43.7 \\
\hline MCV (fL) & 88.32 & 88.28 \\
\hline $\mathrm{MCH}$ (pg) & 32.39 & 33.13 \\
\hline MCHC (\%) & 36.67 & 37.52 \\
\hline Platelets $(103 / \mu \mathrm{l})$ & 352 & 237 \\
\hline WBC $(103 / \mu \mathrm{l})$ & 15.6 & 18.8 \\
\hline Banded/ $\mu \mathrm{l}$ & 0 & 0 \\
\hline Segmented/ $\mu \mathrm{l}$ & 8424 & 14476 \\
\hline 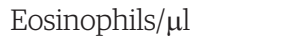 & 0 & 376 \\
\hline 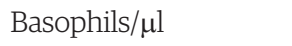 & 0 & 188 \\
\hline 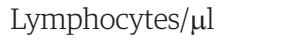 & 6552 & 2444 \\
\hline Monocytes/ $\mu \mathrm{l}$ & 624 & 1316 \\
\hline GGT (UL) & 3630 & --- \\
\hline AST (UL) & 282 & --- \\
\hline ALT (UL) & 30 & 62 \\
\hline FA (UL) & 98 & --- \\
\hline Creatinine (mg/dL) & 0.40 & 0.20 \\
\hline Urea (mg/dL) & 31 & 36 \\
\hline Total protein (g/dL) & 7.5 & --- \\
\hline Albumin (g/dL) & 3.34 & --- \\
\hline Globulin (g/dL) & 4.16 & --- \\
\hline Phosphorus (mg/dL) & 4.9 & --- \\
\hline Dbil (mg/dL) & 5.03 & --- \\
\hline Ibil (mg/dL) & 6.42 & --- \\
\hline Tbil (mg/dL) & 11.45 & --- \\
\hline
\end{tabular}

*Icteric serum; **discrete polychromasia, red blood cell (RBC), hemoglobin (Hb), packed cell volume (PCV), mean corpuscular volume (MCV), mean corpuscular hemoglobin ( $M C H$ ), mean corpuscular hemoglobin concentration (MCHC), white blood cells (WBC), gammaglutamyl transferase (GGT), aspartate aminotransferase (AST), alanine aminotransferase (ALT), alkaline phosphatase (FA), direct bilirubin (Dbil), indirect bilirubin (Ibil), total bilirubin (Tbil). Parameters with --- were not measured. 
with biliary sludge, was observed in the dependent portion. The cystic duct was tortuous and dilated, measuring $1.2 \mathrm{~cm}$ in diameter. These findings suggested a case of cholangiohepatitis due to obstruction of extrahepatic bile ducts, and although it was possible to observe most of the hepatic parenchyma, the possibility of an infiltrative lesion causing extrinsic compression of the biliary system was not discounted.

The animal received medical therapy with antibiotics (Amoxicillin/clavulanate), ursodeoxycholic acid, dipyrone, vitamin and mineral supplementation, oral hydration, and forced feeding based on its feeding habits. However, after one-week home treatment, the clinical presentation progressed, with more severe dehydration and jaundice. Fresh blood counts were performed revealing results similar within the first exam, except for the WBC count, which was even higher (Table 1). In the biochemistry, the level of creatinine had decreased, however, the values for urea and ALT had increased (Table 1). Ultrasonography showed the persistence of the gallbladder enlargement, and ultrasonography-guided cystocentesis revealed dark brown urine. A palpable structure was already present in liver topology, strongly suggesting a case of cholestasis. Urine examination revealed high levels of bilirubin and occult blood. Sedimentation of this material showed the presence of leucocytes and erythrocytes. The animal was submitted to surgery.

\section{Surgical procedure}

Wide trichotomy was performed on the patient's abdomen and thorax, followed by application of an antiseptic solution. The abdominal cavity was accessed via a right paracostal celiotomy. The gallbladder was exposed, and white patches were observed throughout its length. Bile sample was collected by cholecystocentesis and no significant changes were observed on cytological analysis. There was a solid mass throughout the common bile duct. Aspiration biopsy specimens were collected from the mass, liver, and gallbladder for histopathological and immunohistochemical evaluation. An incision was made in the ventral border of the gallbladder and a urethral catheter was used to prove the obstruction of the bile duct. Given the impossibility of resection of the whole mass, cholecystoduodenostomy was performed (Khan et al., 2005; Mayhew \& Weisse, 2013), aiming to eliminate the severe cholestasis and improve the patient's clinical condition. For this purpose, an enterotomy was performed on the cranial portion of the antimesenteric border of the duodenum, near to the major duodenal papilla, and sutured to an incision in the ventral border of the gallbladder, with 3-0 nylon strands, in a separate, single-suture pattern. The surgical procedure was finished with omentalization of all incisions. The abdominal wall was sutured in a sultan pattern with 2-0 nylon strands, and a modified Cushing pattern with nylon 3-0 strand was used to approximate the subcutaneous tissue.

Despite the success of the procedure, the animal had cardiorespiratory arrest at 3.5 hours in the postoperative period, evolving to death. Unfortunately, the owner did not allow a necropsy of the animal.

\section{Histopathological and immunohistochemical analysis}

The samples obtained during the surgery from the bile duct mass, liver, and gallbladder were processed for histopathological and immunohistochemical analysis. After fixation in $10 \%$ buffered formalin for $24 \mathrm{~h}$, the samples were dehydrated, embedded in paraffin, cut into $5-\mu \mathrm{m}$ sections, and stained with hematoxylin and eosin (HE) for histopathological evaluation. Immunohistochemical (IHC) analysis aiming to establish the tumor histogenesis used Cytokeratin (clone AE1/AE3, Dako North America Inc. Carpinteria, CA, USA, cod. M3515, dilution 1:200) and vimentin (clone V9, Dako Denmark. Glostrup, Denmark, cod. M0725, dilution 1:150) antibodies. For this purpose, tissue sections of the bile duct mass were deparaffinized in a stove, at $60^{\circ} \mathrm{C}$, for one hour. They were then plated in absolute xylene for 20 minutes, followed by soaking in decreasing ethylic alcohol solutions, until the tissue was hydrated in distilled water. In order to proceed with immunostaining with the referred antibodies, an antigenic recuperation by heat was performed (Pascal pressure chamber, Dako North America Inc. Carpinteria, CA, USA) in a sodium citrate buffer solution $10 \mathrm{mM}$ (pH 6.0). Subsequently, blocking of endogenous peroxidase with hydrogen peroxide 30 volumes (Merck) was performed, added to methyl alcohol, achieving a final solution with a concentration of $8 \%$, for 30 minutes. The blocking of unspecific proteins was then carried out with a commercial product (Protein Block, Dako North America Inc. Carpinteria, CA, 
USA, cod. X0909), for 30 minutes, at room temperature. The incubation of primary antibodies was performed in a humid chamber, at $4^{\circ} \mathrm{C}$, for 18 hours. The Streptavidin-Biotin Peroxidase Complex kit (Kit LSAB, Dako North America Inc. Carpinteria, CA, USA, cod. K0690) was used as a secondary complex. Diaminobenzidine was the chromogen used (DAB, Dako North America Inc. Carpinteria, CA, USA, cod. S3O22-2) and the counterstaining was elaborated with Harris Hematoxylin. The negative control reaction was performed by replacing the primary antibody by antibody diluent (Dako North America Inc. Carpinteria, CA, USA, cod. S302283-2). The positive control reaction was performed according to the manufacturer's recommendation. The slides were examined and photographed under an Olympus BX-51 light microscope.

Histological examination of the liver showed diffuse accentuated vacuolization of hepatocytes, leading to a swollen appearance of these cells and poor evidence of sinusoids. There were areas of coagulative necrosis, mainly around the centrilobular vein, and accumulation of brownish material inside hepatocytes (hemosiderin). In the portal region, an accentuated proliferation of biliary ducts was observed, which presented replete with bilirubin and with a coalescent arrangement around portal spaces, However, there was no cellular atypia. Discrete neutrophilic inflammatory infiltrates and fibrosis were also noted (Figure 1A). The bile duct mass showed a cellular proliferation of epithelial origin, arranged in cords or islands and occasionally isolated, distributed in a fibrocollagenous stroma with an infiltrative growth pattern (Figure 1B). These cells were polyhedral in shape with defined limits, acidophilic cytoplasm, predominantly oval

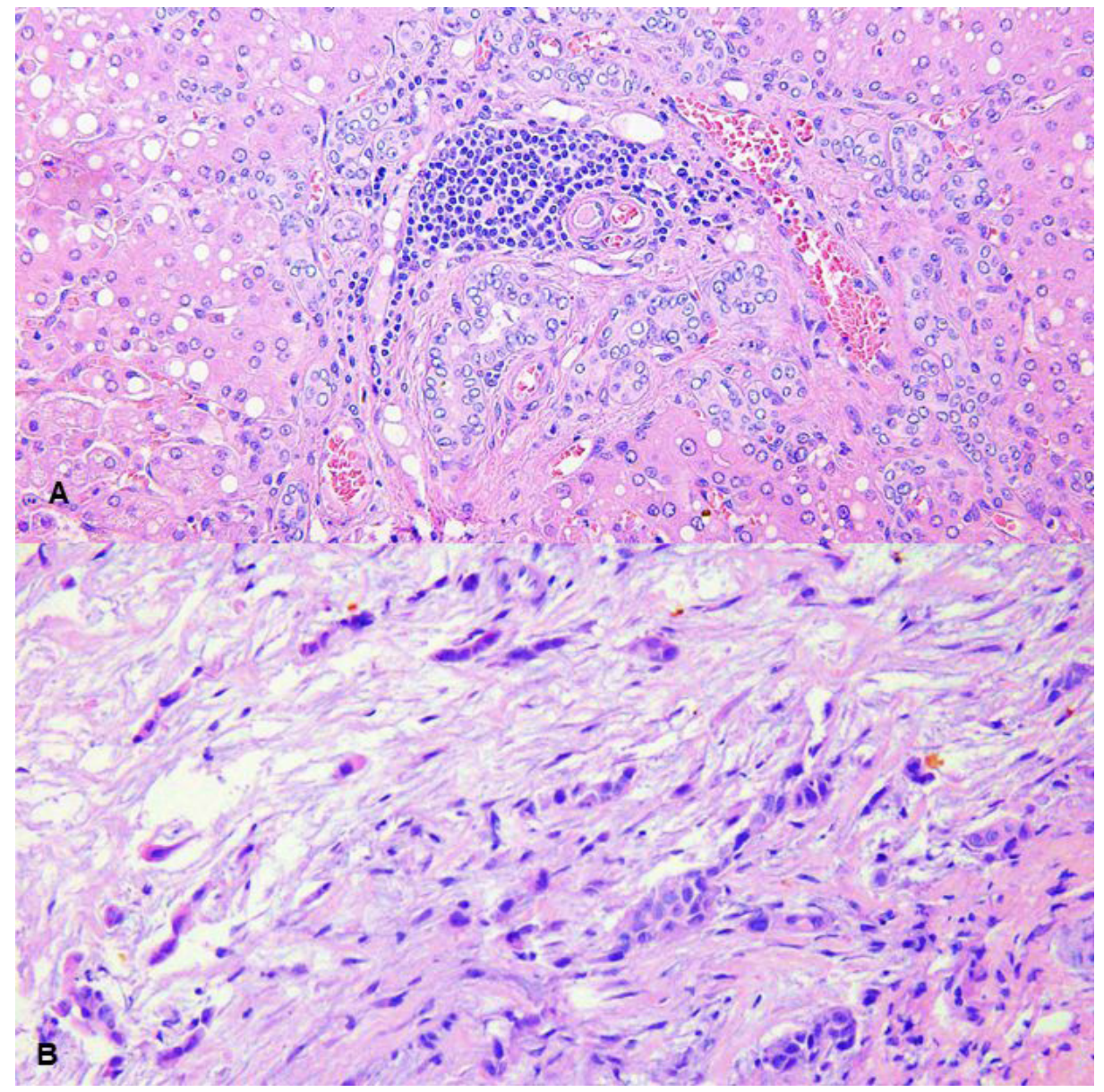

Figure 1. Photomicrographs of the liver and neoplasm tissue of extra-hepatic cholangiocarcinoma in an adult Black Howler Monkey (Alouatta caraya). (A) Liver tissue showing vacuolization of hepatocytes, leading to a swollen appearance, a portal region with the accentuated proliferation of biliary ducts and mononuclear inflammatory infiltrate. Hematoxylin-eosin staining (200x); (B) Bile duct mass tissue, showing proliferation of neoplastic cells with infiltrative growth pattern, arranged in cords or islands, and occasionally isolated in the abundant fibrous stroma. Hematoxylin-eosin staining (200x). 
nuclei with heterogeneous chromatin and evidence of a single nucleolus, occasionally acidophilic. Pronounced anisocytosis and anisokaryosis were also observed, along with necrosis of the cells in the islands. There was no evidence of mitosis figures in the high-power field (HPF). The histopathological analysis of the gallbladder revealed no abnormalities.

In the immunohistochemical analysis performed with the bile duct mass tissue sections, the cytoplasm and nuclei of the cells were marked with diffuse immunostaining with cytokeratin antibodies (Figure 2A), while the cells of the supporting tissue were marked by vimentin antibodies (Figure 2B), confirming the epithelial origin of these cells.

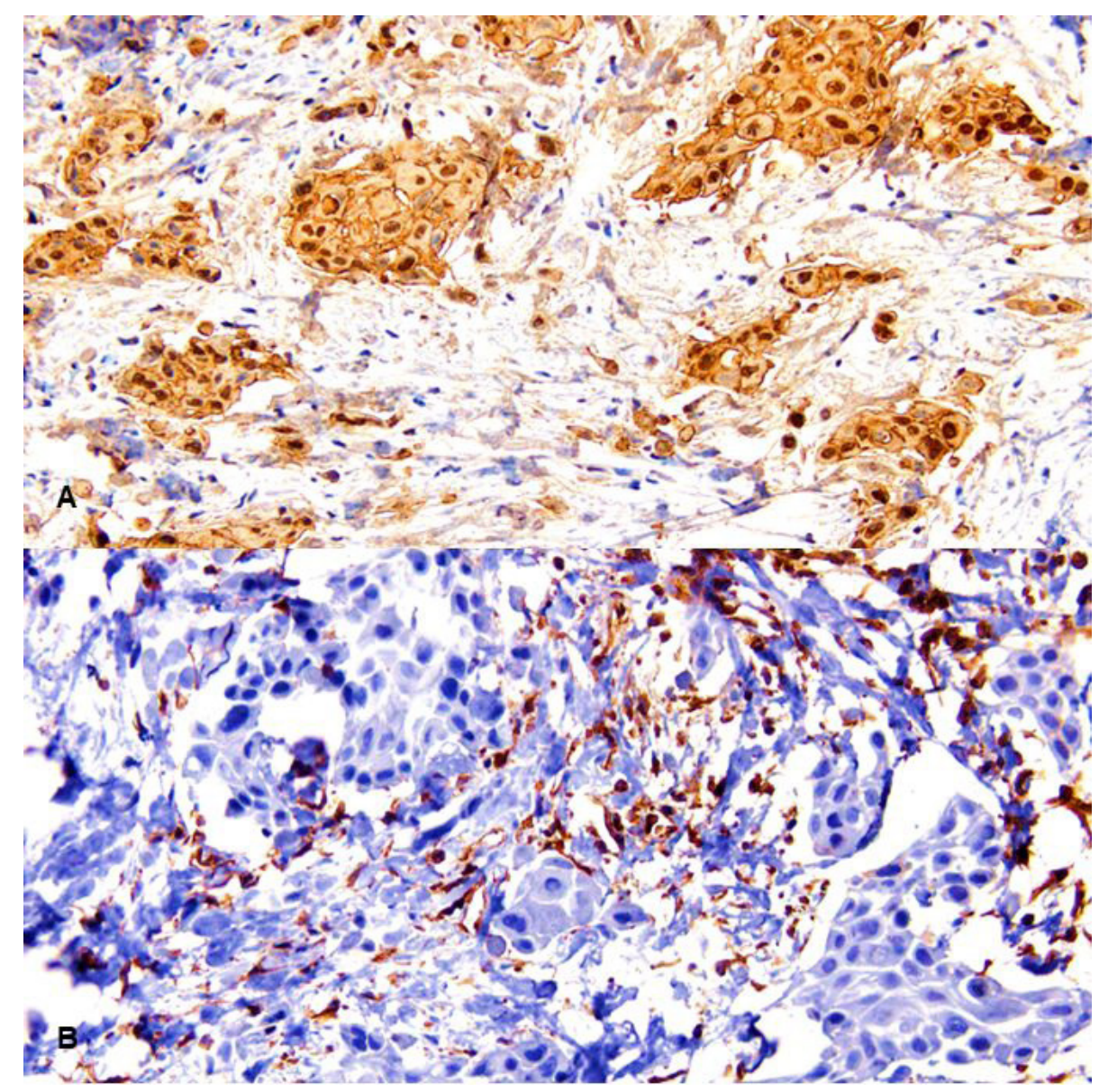

Figure 2. Photomicrographs of immunohistochemical features of extra-hepatic cholangiocarcinoma in an adult Black Howler Monkey (Alouatta caraya). (A) Neoplastic cells with marked and diffuse immunostaining by the cytokeratin antibody in the cytoplasm and nuclei (200x); (B) Neoplastic cells labeled by vimentin antibody, note positive cells in the neoplastic stroma. Streptavidin-Biotin Peroxidase Complex (200x).

Compliance with ethical standards: Animal procedures and management protocols were approved by the Ethics Committee on Animal Use (CEUA) of the School of Agricultural and Veterinarian Sciences (FCAV/Unesp) (protocol number 015785/18).

\section{Discussion}

Herein, we report an extra-hepatic cholangiocarcinoma in an adult Black Howler Monkey. Although the reports of neoplasms in nonhuman primates have considerably increased over the past years, they are still infrequent. Cholangiocarcinomas account for $3 \%$ of all digestive tract neoplasms in humans, being the second most common liver tumor. The tumor originates in 
the biliary tree, being characterized as intrahepatic or extrahepatic (extrahepatic bile ducts); the latter being rarer since they are associated with gallbladder neoplasms (Khan et al., 2005; Ka etal., 2018). The primary causes of cholangiocarcinoma include primary sclerosing cholangitis (Shaib \& El-Serag, 2004), parasitic infections (Watanapa \& Watanapa, 2002), fibropolycystic liver disease (Scott et al., 1980), intrahepatic biliary calculi (Shaib \& El-Serag, 2004), chemical carcinogens (Sahani et al., 2003), viral hepatitis, and cirrhosis (Shaib et al., 2005).

This type of tumor has a late clinical presentation, and it is characterized by high mortality rates since treatments become ineffective due to its wide extension. The most evident sign of the tumoral affection is jaundice, which was present in this patient, and is commonly observed in advanced stages (Blanchet et al., 2000). In this report, the large extension of the tumoral mass precluded complete resection and the clearing of the bile duct. In humans, this type of tumor is mostly unresectable when diagnosed, resulting in death within a maximum of 12 months, due to cancer cachexia, liver failure, and severe biliary obstruction, which can progress to sepsis (Khan et al., 2005). In human patients when resection is possible, survival is about $5 \%$ and the patients usually survive less than 5 years (Shaib \& El-Serag, 2004); no such information is available for non-human primates.

Usually, ultrasonographic examination represents a suitable method for diagnosis of hepatobiliary neoplasms; in addition, secondary alterations such as dilatation of the bile ducts may be observed. However, for definitive diagnosis and prognosis, computed tomography and magnetic resonance imaging are required, the last one giving the information about extension and possibility of resection of the mass (Khan et al., 2005; Skiker et al., 2007).

The patient in this report presented clinical signs and laboratory results compatible with liver disease (Table 1). The significant increase in GGT (3630 $\mu \mathrm{g} / \mathrm{dl})$, a cholestasis-marking enzyme, is associated with direct changes in the bile ducts since this enzyme is present in the membrane of the cells of the biliary tree (Nelson \& Couto, 2014). The AST enzyme was also increased ( $282 \mu \mathrm{g} / \mathrm{dl}$ ) indicating hepatocyte death, as it occurs both in the cytosol and in the hepatocyte mitochondria (Silva, 2015). The expressive increase in serum bilirubin also indicated evident changes in the hepatobiliary system, with bile stasis resulting in jaundice. In addition, the ultrasonographic evaluation showed dilation of the cystic duct, replete gallbladder and hepatic congestion, evident signs of biliary tract obstruction. Precluded from performing more accurate imaging tests, such as computed tomography or magnetic resonance imaging, cholecystoduodenostomy was indicated for decompression of the biliary tract, thus treating the severe cholestasis.

Histopathological samples collected from the mass confirmed the diagnosis of extrahepatic cholangiocarcinoma. Alterations observed in the histological samples of the liver such as vacuolization, necrosis, and hemosiderin accumulation, occurred due to the bile duct obstruction; despite the accentuated proliferation of biliary ducts observed in the portal region, these cells showed no atypia, suggesting a process of tissue regeneration instead of a neoplastic process.

Therapies such as antineoplastic chemotherapy and radiation therapy are not associated with a good therapeutic response in cholangiocarcinoma, therefore, tumor resection is the most effective treatment. Frequently, palliative care such as drainage or diversion of the biliary flow are performed, in attempt to reduce the signs and symptoms of cholestasis (Khan et al., 2005).

On radiographic examination, it was possible to visualize alterations compatible with pulmonary neoplasm, however, due to non-authorization of necropsy, it was not possible to confirm the presence of another neoplasm. In general, it could possibly have been an aggravating factor in the patient's clinical condition.

\section{Conclusion}

To the best of our knowledge, this is the first report of an extra-hepatic cholangiocarcinoma in a Black Howler Monkey. Since tumor resection was not possible due to its large extension, a cholecystoduodenostomy was performed in an attempt to treat the severe cholestasis that was present and improve the patient's condition. Despite these efforts, the patient died hours after, evidencing the severity of the clinical condition. 


\section{Acknowledgements}

The authors thank the members of the Clinical Pathology Laboratory of São Paulo State University (UNESP), Jaboticabal, for logistical aid and sample processing.

\section{References}

Abe, K., Kagei, N., Teramura, Y., \& Ejima, H. (1993). Hepatocellular carcinoma associated with chronic Schistosoma mansoni infection in a chimpanzee. Journal of Medical Primatology, 22(4), 237-239. PMid:8230173.

Blanchet, M. C., Ducerf, C., Benoit, L., Gérard, J. P., \& Baulieux, J. (2000). Cholangiocarcinomes de la voie biliaire principale proximale. Annales de Chirurgie, 125(9), 825-831. http://dx.doi.org/10.1016/S0003-3944(00)000158. PMid:11244588.

Borda, J. T., Ruiz, J. C., \& Sanchez-Negrette, M. (1996). Spontaneous hepatocellular carcinoma in Saimiri boliviensis. Veterinary Pathology, 33(6), 724-726. http://dx.doi.org/10.1177/030098589603300617. PMid:8952037.

Brown, R. J., O'Neill, T. P., Kessler, M. J., \& Andress, D. (1980). Cholangiocarcinoma in a capuchin monkey (Cebus albifrons). Veterinary Pathology, 17(5), 626-629. http://dx.doi.org/10.1177/030098588001700512. PMid:6250275.

Canales-Espinosa, D., Jesus Rovirosa-Hernández, M., Thoisy, B., Caba, M., \& García-Orduña, F. (2015). Hematology and serum biochemistry in wild howler monkeys. In M. M. Kowalewski, P. A. Garber, L. Cortés-Ortiz, B. Urbani \&D. Youlatos (Eds.), Howler monkeys. Developments in primatology: progress and prospects (pp.179-202). New York: Springer. https://doi.org/10.1007/978-1-4939-1957-4_7.

Catão-Dias, J. L., Montali, R. J., Strandberg, J. D., Johnson, L. K., \& Wolff, M. J. (1996). Endocrine neoplasia in New World primates. Journal of Medical Primatology, 25(1), 34-41. http://dx.doi.org/10.1111/j.1600-0684.1996. tb00190.x. PMid:8740950.

Chang, J., Wagner, J. L., \& Kornegay, R. W. (1979). Spontaneous cholangiocarcinoma in a ring-tailed lemur (Lemur catta). Laboratory Animal Science, 29(3), 374-376. PMid:228114.

Johnson, L. D., Ausman, L. M., Sehgal, P. K., \& King Junior, N. W. (1996). A prospective study of the epidemiology of colitis and colon cancer in cotton-top tamarins (Saguinus oedipus). Gastroenterology, 110(1), 102-115. http:// dx.doi.org/10.1053/gast.1996.v110.pm8536845. PMid:8536845.

Juan-Sallés, C., Ramos-Vara, J. A., \& Garner, M. M. (2009). Pheochromocytoma in six new world primates. Veterinary Pathology, 46(4), 662-666. http://dx.doi.org/10.1354/vp.08-VP-0275-J-BC. PMid:19276065.

Ka, I., Faye, M., Diop, P. S., Niang, A. B., Ndoye, J. M., \& Fall, B. (2018). Cancers biliaires: aspects épidémiologiques cliniques et thérapeutiques à propos de 20 cas. The Pan African Medical Journal, 29, 29. http://dx.doi. org/10.11604/pamj.2018.29.13.9922.

Kaspareit, J., Friderichs-Gromoll, S., Buse, E., \& Habermann, G. (2007). Spontaneous neoplasms observed in cynomolgus monkeys (Macaca fascicularis) during a 15-year period. Experimental and Toxicologic Pathology, 59(3-4), 163-169. http://dx.doi.org/10.1016/j.etp.2007.06.001. PMid:17869495.

Khan, S. A., Thomas, H. C., Davidson, B. R., \& Taylor-Robinson, S. D. (2005). Cholangiocarcinoma. Lancet, 366(9493), 1303-1314. http://dx.doi.org/10.1016/S0140-6736(05)67530-7. PMid:16214602.

Lowenstine, L. J. (1986). Neoplasms and proliferative disorders in nonhuman primates. In K. Benirschke (Ed.), The road to self-sustaining populations (pp. 781- 814). New York: Springer-Verlag. http://dx.doi. org/10.1007/978-1-4612-4918-4_53.

Maruffo, C. A. (1967). Spontaneous tumours in howler monkeys. Nature, 213(5075), 521. http://dx.doi. org/10.1038/213521aO. PMid:4962854.

Maruffo, C. A., \& Malinow, M. R. (1996). Seminoma in a howler monkey (Alouatta caraya). The Journal of Pathology, 91(1), 280-282. http://dx.doi.org/10.1002/path.1700910139. PMid:5949573.

Mayhew, P. D., \& Weisse, C. (2013). Liver and biliary system. In K. M. Tobias \& S. A. Johnston (Eds.), Veterinary surgery small animal (2nd ed., pp. 4948-5020). St. Louis: Elsevier.

Mayhew, P. D., Holt, D. E., Mc Lear, R. C., \& Washabau, R. J. (2002). Pathogenesis and outcome of extrahepatic biliary obstruction in cat. The Journal of Small Animal Practice, 43(6), 247-253. http://dx.doi.org/10.1111/j.1748-5827.2002. tb00067.x. PMid:12074289.

Nelson, R. W., \& Couto, C. G. (2014). Hepatobiliary disease in the cat. In: R. W. Nelson \& C. G. Couto (Eds.), Small animal internal medicine (5th ed., pp. 520-540). California: Elsevier.

Rylands, A. B., Valladares-Pádua, C., Rocha e Silva, R., Boere, V., Catão-Dias, J. L., Pissinatti, A., \& Guimarães, M. A. B. V. (2001). Order primates (primates). In M. E. Fowler \& Z. S. Cubas (Eds.), Biology, medicine, and surgery of South American wild animals (pp. 256-278). Iowa: Iowa State University Press.

Sahani, D., Prasad, S. R., Tannabe, K. K., Hahn, P. F., Mueller, P. R., \& Saini, S. (2003). Thorotrast-induced cholangiocarcinoma: case report. Abdominal Imaging, 28(1), 72-74. http://dx.doi.org/10.1007/s00261-0010148-y. PMid:12483389.

Scott, J., Shousha, S., Thomas, H. C., \& Sherlock, S. (1980). Bile duct carcinoma: a late complication of congenital hepatic fibrosis: case report and review of literature. The American Journal of Gastroenterology, 73(2), 113-119. PMid:6249119. 
Seibold, H. R., \& Wolf, R. H. (1973). Neoplasms and proliferative lesions in 1065 nonhuman primate necropsies. Laboratory Animal Science, 23(4), 533-539. PMid:4354707.

Shaib, Y. H., El-Serag, H. B., Davila, J. A., Morgan, R., \& McGlynn, K. A. (2005). Risk factors of intrahepatic cholangiocarcinoma in the United States: a case-control study. Gastroenterology, 128(3), 620-626. http:// dx.doi.org/10.1053/j.gastro.2004.12.048. PMid:15765398.

Shaib, Y., \& El-Serag, H. B. (2004). The epidemiology of cholangiocarcinoma. Seminars in Liver Disease, 24(2), 115-125. http://dx.doi.org/10.1055/s-2004-828889. PMid:15192785.

Silva, D. R. (2015). Avaliação laboratorial do sistema hepatobiliar. In M. M. Jericó (Ed.), Tratado de medicina interna de cães e gatos (pp. 3139-3152). Rio de Janeiro: Rocca.

Skiker, I., Semlali, S., Nouali-En, H., Amil, T., Benameur, M., \& Chaouir, S. (2007). Apport de l'imagerie dans les tumeurs malignes des voies biliaires intra et extra-hepatiques: étude de 14 cas. Journal de Radiologie, 87: 1535.

Watanapa, P., \& Watanapa, W. B. (2002). Liver fluke-associated cholangiocarcinoma. British Journal of Surgery, 89(8), 962-970. http://dx.doi.org/10.1046/j.1365-2168.2002.02143.x. PMid:12153620. 